\title{
Guest editorial: the 2016 central Italy earthquakes
}

\author{
Angelo Masi ${ }^{1,2} \cdot$ Andrea Penna ${ }^{3,4}$
}

Received: 12 August 2019 / Accepted: 17 August 2019 / Published online: 29 August 2019 (c) Springer Nature B.V. 2019

The subject of this Special Issue is the seismic sequence that struck central Italy mainly in 2016, and continuing in the first months of 2017. More than 92,000 ground motions were recorded in central Italy between summer 2016 and spring 2017, with a total of 9 events of magnitude higher than 5. The major earthquakes in the series, all associated with normal faults belonging to the complex central Apennine mountain range fault system with NW-SE or NNW-SSE strike, were:

- $M$ 6.0, August 24th, 2016, mostly affecting the municipalities of Accumoli, Amatrice and Arquata del Tronto;

- M 5.9, October 26th, 2016, mostly affecting Castelsantangelo sul Nera, Visso, Ussita and Preci;

- M 6.5, October 30th, 2016, mostly affecting Norcia, Castelsantangelo sul Nera and Preci;

- M 5.0, January 18th, 2017, mostly affecting Capitignano, Amatrice and Campotosto.

According to the most recent report of the Italian Civil Protection Department (DPC 2018) the earthquake sequence caused 299 victims, all due to the August 24th event and distributed in the municipalities of Amatrice (237), Accumoli (11) and Arquata del Tronto (51, all concentrated in the settlement of Pescara del Tronto). This terrible outcome was also caused to the unfortunate occurrence of this shallow earthquake, the first one in the sequence and with a PGA value recorded in Amatrice equal to $0.87 \mathrm{~g}$, during the highest touristic season. Luckily, the events of October 26th and October 30th did not cause further victims. About 400 injuried people needed hospitalization.

The most affected area extended over the territory of 4 different Italian regions (Lazio, Umbria, Marche and Abruzzo), with a total land area of about $8000 \mathrm{~km}^{2}$ and a population of approximately 600,000 inhabitants. The number of homeless people exceeds 30,000 in November 2016.

The articles included in this special issue deal with several key aspects of this earthquake sequence, namely:

Angelo Masi

angelo.masi@unibas.it

1 School of Engineering, University of Basilicata, Potenza, Italy

2 Network of the University Laboratories of Earthquake Engineering (ReLUIS), Naples, Italy

3 Department of Civil Engineering and Architecture, University of Pavia, Pavia, Italy

4 European Centre for Training and Research in Earthquake Engineering, Pavia, Italy 
- Characteristics of the seismic action, considering recorded ground motions and the associated structural demand, combined effects of specific site responses and building vulnerability on observed consequences, geotechnical effects on structures/infrastructures and environment;

- Large scale assessment and comparisons, via numerical reproduction of damage scenarios based on simplified mechanics-based damage vulnerability models, and studies on the effects of damage cumulation on the assessment of macroseismic intensity;

- Damage in residential buildings, mostly old stone masonry and reinforced concrete (RC) structures, non-structural damage and effectiveness of retrofit strategies applied after recent seismic events;

- Performance of public facilities including schools, hospitals, bridges and churches.

Five manuscripts in the special issue analyze the characteristics of the seismic action of the earthquakes in the sequence and focus on different aspects of structural demand and geotechnical effects:

- Mollaioli et al. (2018) analyze the observed seismic damage in correlation with the assessment of the damage potential of the recorded ground motions, highlighting the high severity of the main events in the sequence.

- Iervolino et al. (2018) focus on the ground shaking in the near-source region where code seismic actions were unsurprisingly exceeded, the damaging potential of ground motions was extremely high, also considering the expected nonlinear response of vulnerable structures cumulating damages along the sequence.

- Laurenzano et al. (2018) present a study on the site response of a number of sites in the municipalities of Arquata del Tronto and Montegallo based on seismological data.

- Pescara del Tronto and Vezzano, two neighbouring settlements in the municipality of Arquata del Tronto, are also studied by Vignola et al. (2018) in their contribution on geophysical and engineering analysis of very different damage levels found after the August 24th, 2016, event.

- Following the Italy-US GEER post-earthquake reconnaissance missions, Lanzo et al. (2018) report geotechnical earthquake effects on slopes, buildings and major infrastructures, including dams, retaining walls and road embankments.

Two manuscripts report interesting applications of large scale assessment procedures, both highlighting aspects that could improve future applications:

- Graziani et al. (2019) consider the damage assessment and macroseismic intensities surveyed after the damaging shocks in the sequence, focusing on their evolution in Amatrice, Accumoli and Arquata del Tronto, between the two main events of 2016.

- Borzi et al. (2018) compute damage scenarios for the main events of 2016 using the WebGIS platform developed by the Eucentre Foundation for the Italian Department of Civil Protection.

The stock of residential buildings in the affected area is rather inhomogenous, presenting mostly unreinforced masonry and RC structures with various vulnerability due to different materials, characteristics and detailing, depending on the different availability of construction materials, the history of the settlement, the occurrence of past seismic events and possible reconstruction policies adopted over time, the year of first seismic classification of the 
municipality and the demographic trend causing in many cases lack of building maintenance. Four articles address these issues:

- Sorrentino et al. (2018) study the behavior of ordinary masonry buildings, i.e. more than three quarters of all constructions in the area, focusing in particular on the municipalities of Amatrice, Arquata del Tronto, Accumoli, Castelsantangelo sul Nera and Norcia and highlighting the role in old masonry structures of the specific vulnerability factors associated with different material properties (mortar), structural features (number of stories), details (presence of effective connections) and past retrofit interventions.

- Sisti et al. (2018) report the analysis of the clear effectiveness of strengthening techniques implemented in masonry buildings in Norcia after the seismic events that stroke the city in 1971, 1979 and 1997, which significantly reduced the seismic vulnerability in comparison to similar buildings in other municipalities/regions.

- Masi et al. (2018) analyse the response of RC buildings in Amatrice, reporting the heavy damage conditions associated with masonry infills and their interaction with RC frames and comparing observed damage to damage predictions obtained with the POST method.

- Perrone et al. (2018) focus on the seismic damage to non-structural elements, which systematically included partition walls, ceiling systems, chimneys, as well as non-structural vaults and stuccoes.

The seismic performance of public buildings and facilities was in many cases poor, reflecting a general need for effective policies and investments on their seismic safety. Four papers deal with public buildings, infrastructures and heritage structures:

- Di Ludovico et al. (2018) present the outcome of post-earthquake inspections carried out on 1514 school building structures in the aftermath of the 2016 earthquake, analysing the usability results in correlation with the buildings characteristics, seismic action and damage to structural and non-structural components;

- Santarsiero et al. (2018) present an overview on the response of the healthcare system starting from the survey of 5 hospital complexes, which resulted partially or totally unusable with heavy consequences on the healthcare services and transfer of patients to other hospitals;

- Di Sarno et al. (2018) report on the performance of masonry and RC bridges in the epicentral area, which generally experienced some damage, but resulted sufficiently safe in terms of prevention of collapse;

- Penna et al. (2019) present the result of post-earthquake surveys to churches which, due to their intrinsically high vulnerability, were found damaged at significant distances from the epicentres, hence involving an extremely large territory (about 30,000 $\mathrm{km}^{2}$ ).

The experience of this sequence offers several lessons that should be learnt to improve preparedness and prevention actions.

The unique circumstances of the earthquake sequence, also due to the number of strong events striking a wide and mostly mountain area, partially damaging the road system and followed by an exceptionally snowy winter, made the emergency management and rehabilitation process even more complicated.

With specific reference to prevention, the seismic performance of the built environment observed during the 2016-2017 Central Italy earthquake sequence highlights once more the high fragility of the territory, confirming the need for preventive actions to guarantee 
acceptable levels of protection and functionality, both in private residential buildings and in public facilities and infrastructures. To this end, the articles included in this special issue offer a first basis for a wider discussion on both the development of the reconstruction programs to be carried out locally and the definition of an effective and general strategy of risk mitigation.

Acknowledgements As Guest Editors of this special issue of the Bulletin of Earthquake Engineering, we would like to thank the authors for their valuable contribution, the international panel of reviewers, the Editor in Chief of the Bulletin, Professor Atilla Ansal, and the technical staff of Springer for all their efforts. Moreover, it is worth noting that part of the articles included in this special issue are the result of the fruitful cooperation between the ReLUIS Consortium, the Eucentre Foundation and the EERI Institute, which also co-organized two specific reconnaissance field missions in September 2016 and in May 2017.

\section{References}

Borzi B, Faravelli M, Polli DA (2018) Central Italy sequence: simulated damage scenario for the main 2016 shocks. Bull Earthq Eng. https://doi.org/10.1007/s10518-018-0378-9

Di Ludovico M, Digrisolo A, Moroni C, Borri A, Dall'Asta A, Graziotti F, Manfredi V, Prota A, Dolce M, Manfredi G (2018) Remarks on damage and response of school buildings during the central Italy earthquake sequence. Bull Earthq Eng. https://doi.org/10.1007/s10518-018-0332-x

Di Sarno L, da Porto F, Guerrini G, Calvi PM, Camata G, Prota A (2018) Seismic performance of bridges during the 2016 Central Italy earthquakes. Bull Earthq Eng. https://doi.org/10.1007/s1051 8-018-0419-4

DPC (2018) Presidenza del Consiglio dei Ministri, Dipartimento della Protezione Civile, I numeri del sisma, in Centro Italia. www.protezionecivile.gov.it. Accessed on January 2019, in Italian

Graziani L, Del Mese S, Tertulliani A, Arcoraci L, Maramai A, Rossi A (2019) Investigation on damage progression during the 2016-2017 seismic sequence in Central Italy using the European macroseismic scale (EMS-98). Bull Earthq Eng. https://doi.org/10.1007/s10518-019-00645-w

Iervolino I, Baltzopoulos G, Chioccarelli E, Suzuki A (2018) Seismic actions on structures in the nearsource region of the 2016 Central Italy sequence. Bull Earthq Eng. https://doi.org/10.1007/s1051 8-017-0295-3

Lanzo G, Tommasi P, Ausilio E, Aversa S, Bozzoni F, Cairo R, d'Onofrio A, Durante MG, Foti S, Giallini S, Mucciacciaro M, Pagliaroli A, Sica S, Silvestri F, Vessia G, Zimmaro P (2018) Reconnaissance of geotechnical aspects of the 2016 Central Italy earthquakes. Bull Earthq Eng. https://doi.org/10.1007/ s10518-018-0350-8

Laurenzano G, Barnaba C, Romano MA, Priolo E, Bertoni M, Bragato P, Comelli P, Dreossi I, Garbin M (2018) The central Italy 2016-2017 seismic sequence-site response analysis based on seismological data in the arquata del tronto-montegallo municipalities. Bull Earthq Eng. https://doi.org/10.1007/ s10518-018-0355-3

Masi A, Chiauzzi L, Santarsiero G, Manfredi V, Biondi S, Spacone E, Del Gaudio C, Ricci P, Manfredi G, Verderame GM (2018) Seismic response of RC buildings during the Mw 6.0 August 24, 2016 Central Italy earthquake: the Amatrice case study. Bull Earthq Eng. https://doi.org/10.1007/s1051 8-017-0277-5

Mollaioli F, AlShawa O, Liberatore L, Liberatore D, Sorrentino L (2018) Seismic demand of the 2016-2017 Central Italy earthquake. Bull Earthq Eng. https://doi.org/10.1007/s10518-018-0449-y

Penna A, Calderini C, Sorrentino L, Carocci CF, Cescatti E, Sisti R, Borri A, Modena C, Prota A (2019) Damage to churches in the 2016 Central Italy earthquakes. Bull Earthq Eng. https://doi.org/10.1007/ s10518-019-00594-4

Perrone D, Calvi PM, Nascimbene R, Fischer E, Magliulo G (2018) Seismic performance of non-structural elements during the 2016 Central Italy earthquake. Bull Earthq Eng. https://doi.org/10.1007/s1051 8-018-0361-5

Santarsiero G, Masi A, Di Sarno L, Biondi S, Cosenza E, Giovinazzi S (2018) Performance of the healthcare facilities during the 2016-2017 Central Italy seismic sequence. Bull Earthq Eng. https://doi. org/10.1007/s10518-018-0330-Z 
Sisti R, Di Ludovico M, Borri A, Prota A (2018) Damage assessment and the effectiveness of prevention: the response in buildings in Norcia. Bull Earthq Eng. https://doi.org/10.1007/s10518-018-0448-z

Sorrentino L, Cattari S, da Porto F, Magenes G, Penna A (2018) Seismic behaviour of ordinary masonry buildings during the 2016 Central Italy Earthquakes. Bull Earthquake Eng. https://doi.org/10.1007/ s10518-018-0370-4

Vignola L, Gallipoli MR, Chiauzzi L, Stabile TA, Piscitelli S, Santarsiero G, Bellanova J, Calamita G, Perrone A (2018) Geophysical and engineering analysis of different earthquake damage in Pescara del Tronto and Vezzano (Arquata del Tronto Municipality) following the 24th August 2016 central Italy earthquake. Bull Earthq Eng. https://doi.org/10.1007/s10518-018-0450-5

Publisher's Note Springer Nature remains neutral with regard to jurisdictional claims in published maps and institutional affiliations. 